\title{
Has the eco-efficiency of sheep and beef farms changed in the last 20 years?
}

\author{
A.D. MACKAY ${ }^{1}$, A.P. RHODES ${ }^{2}$, I. POWER ${ }^{3}$ and M.E. WEDDERBURN ${ }^{3}$ \\ ${ }^{1}$ AgResearch Grasslands, Private Bag 11008, Palmerston North \\ ${ }^{2} P G G$ Wrightson Consulting, PO Box 42, Dannevirke \\ ${ }^{3}$ AgResearch Ruakura Research Centre East Street, Private Bag 3123, Hamilton \\ alec.mackay@agresearch.co.nz
}

\begin{abstract}
It is timely, with farming within biophysical limits as an emerging feature of the future operating environment for the sector, to explore whether the substantial productivity gains seen in the sheep and beef sector over the last 20 years translate into improved ecoefficiency and a reduction in the sector's environmental footprint. In this paper the changes in the relationship between inputs (e.g., livestock numbers, nutrients) and outputs (e.g., meat and fibre, greenhouse gas (GHG) emissions, nitrate) of the MAF Sheep and Beef Farm Monitoring models that cover hard hill country (Gisborne and Central North Island) and easy hill finishing (Manawatu) over the last 20 years were explored using the Overseer nutrient budget model. For the hard hill country extensive sheep and beef farm operation, the productivity gains made since 1989/90 translate into significant eco-efficiency gains, including a $47 \%$ increase in saleable product/ha (107 to $167 \mathrm{~kg}$ per ha), $21 \%$ reduction in nitrate leaching per $\mathrm{kg}$ of saleable product $(0.065$ to $0.054 \mathrm{~kg} \mathrm{~N}$ per $\mathrm{kg}$ animal product) and $40 \%$ reduction in the GHG emissions per $\mathrm{kg}$ of saleable product (27 to $19.2 \mathrm{~kg} \mathrm{CO}_{2}$-e per kg animal product). The improvements have come through increased meat production. In contrast, the contribution from wool has been unchanged since 1989/90. These eco-efficiency gains, however, did not extend to include an overall reduction in $\mathrm{N}$ leaching or GHG emissions per hectare. In the easy hill finishing operation, where the MAF model farm size more than doubled over the last 20 years, there was little change in the eco-efficiency, but again also little change in total emissions. As we move to an operating environment where there are limits on emissions to the environment, understanding how to quantify eco-efficiency and monitor changes in this performance indicator becomes more than just an academic exercise.
\end{abstract}

Keywords: Sheep and beef, eco-efficiency, meat and fibre production, $\mathrm{N}$ leaching, hill country

\section{Introduction}

The sheep and beef industry has made enormous productivity gains over the last $20+$ years through a combination of new technologies, including advances in animal genetics and health, and improvements in farm practices, such as nutrient, pasture and animal management. National average lambing percentage has increased from 100 to $120 \%$ since 1990 , lamb carcass weight per ewe from 13 to $17 \mathrm{~kg}$ and wool per head from 5 to $6 \mathrm{~kg}$ (Beef+Lamb New Zealand 2012). Numbers of sheep and beef farms have declined over the same period with a $17 \%$ decrease in hill country properties (7500 to 6245) and a $45 \%$ decline in finishing farms (12 100 to 6635). Since 1990 the total hectares in sheep and beef have decreased $28 \%$ from an estimated 12.5 to 9 million hectares in 2012. This decline includes a loss of 0.9 million ha of prime sheep and beef land to dairy production. A further 2.6 million ha has been lost to forestry, extensive marginal pasturelands closed for conservation, reversion to scrub and bush, urban encroachment, viticulture and horticulture. Much of the land lost to urbanisation (percent converted of original extent measured by the Land Resource Inventory) is from Land Use Capability (LUC) Class 1 (5.6\%) and Class 2 (4\%) compared with $<0.01$ to $2.0 \%$ for LUC Classes 3-8 (Rutledge et al. 2010), suggesting that the industry may have lost upwards of another 0.5 million ha of prime sheep and beef land, over and above that lost to dairy.

Despite the decline in the area in sheep and beef, the export value of lamb, sheep meats and beef has more than doubled from $<\$ 2.5$ billion to over $>\$ 5$ billion since 1990 . This can be attributed in part to the on-farm productivity gains achieved by the sector. It would be interesting to explore if these gains translate into improved eco-efficiency and a reduction in the sector's environmental footprint, as farming within biophysical limits is an emerging property of the future environment in which the industry will have to operate. Eco-efficiency is not a new idea and has been used by the industry to examine efficiency for some time. Measures of eco-efficiency include the amount of product per unit input or hectare and or emissions to air and water per unit product or per hectare.

This paper explores the changes in the eco-efficiency of the sheep and beef sector over the last 20 years 
by examining the relationship between inputs (e.g., livestock numbers, nutrients) and outputs (e.g., saleable products, greenhouse gases (GHG), nitrate) for the MAF Sheep and Beef Farm Monitoring models for hard hill country and easy hill finishing operations.

\section{Materials and Methods}

\section{Farm monitoring data}

Ministry of Agriculture and Fisheries (MAF) sheep and beef farm monitoring models (Hard Hill CountryGisborne 1989/90, 1999/2000, 2009/10, Hard Hill Country Central North Island (CNI) that covered the King Country-Taihape areas 1989/90, 1999/2000, 2009/10 and Manawatu Easy Hill Finishing 1989/90, $1999 / 2000,2009 / 10$ ) were used to explore the influence of changes in inputs (e.g., livestock numbers, nutrients) and outputs (e.g., saleable products, GHG, nitrate) since 1989/90. Data were obtained from the MAF Farm monitoring report, National Reports June 1990 (MAF 1990), Sheep and Beef and Dairy monitoring report July 2000 (MAF 2000) and Pastoral monitoring 2011(MAF 2010).

\section{Overseer $^{\circledR}$ nutrient budget model}

Overseer $^{\mathbb{B}}$ nutrient budget model 2009 version 5.4.10 was used to explore the relationship between inputs and outputs from each of these sheep and beef systems. The GHG model built within Overseer is based on algorithms similar to those used for New Zealand's national inventory, modified to allow for on-farm management strategies. The model is increasingly being used as a tool to estimate on-farm GHG emissions from pastoral systems (Wheeler et al. 2008). The GHG emissions reported here are limited to the methane from animals and nitrous oxide emissions from excreta and any applied $\mathrm{N}$ fertiliser. The sheep and beef farms were examined as a single block with other details of the input data and assumptions listed in Table 1.

\section{Meat and Fibre production}

To calculate sheep and beef meat production for Hard Hill Country-CNI and Manawatu easy hill finishing sheep and beef farm systems, a stock reconciliation table was constructed from the information provided in each of the Sheep and Beef Farm Monitoring models. To complete the stock reconciliation and calculate the amount of meat and fibre produced the following assumptions were made: ewe lamb replacement rates of $30 \%$ for the Hard Hill Country-CNI systems, a combination of $11 \%$ ewe lamb replacements plus purchase of two-tooth or mixed age ewes for the easy hill finishing model farm, heifer replacement rates of $20 \%$ for the hard hill country in calculating the number of lambs and cull ewes for sale and number of calves for sale or rearing and cull cows, and death rates of $5 \%$ for sheep and cattle. The carcass weights for store

Table 1 Input information and some of the assumptions made in populating the Overseer $\circledast$ nutrient budget model

\begin{tabular}{|c|c|c|c|c|c|c|c|c|c|}
\hline \multirow{3}{*}{$\begin{array}{l}\text { Sheep and beef } \\
\text { Soil }\end{array}$} & \multicolumn{3}{|c|}{ Gisborne hard hill country } & \multicolumn{3}{|c|}{ Central North Island hard hill country } & \multicolumn{3}{|c|}{$\begin{array}{l}\text { Manawatu Easy Hill Finishing } \\
\text { country }\end{array}$} \\
\hline & $1989 / 1900$ & $1999 / 2000$ & $2009 / 2010$ & $1989 / 1990$ & $1999 / 2000$ & $2009 / 2010$ & $1989 / 1990$ & $1999 / 2000$ & $2009 / 2010$ \\
\hline & Brown & Brown & Brown & Brown & Brown & Brown & Brown & Brown & Brown \\
\hline Rainfall (mm) & 1500 & 1500 & 1500 & 1500 & 1500 & 1500 & 1250 & 1250 & 1250 \\
\hline Pasture & Browntop & Browntop & Browntop & Browntop & Browntop & Browntop & Browntop & Browntop & Browntop \\
\hline Olsen P & 11 & 17.5 & 17.5 & 11 & 17.5 & 17.5 & 17 & 22.5 & 22.5 \\
\hline Stocking rate (su/ha) & 7.8 & 7.9 & 8.7 & 7.8 & 9.2 & 8.4 & 10.3 & 10.3 & 10.6 \\
\hline Sheep (\%) & 72 & 55 & 54 & 72 & 63 & 65 & 69 & 53 & 60 \\
\hline Lambing (\%) & 75 & 110 & 126 & 75 & 103 & 124 & 93 & 123 & 134 \\
\hline Store lamb $(\mathrm{kg})$ & & & & 28.6 & 30.9 & 35 & & & \\
\hline $\begin{array}{l}\text { Prime lamb carcass } \\
(\mathrm{kg})\end{array}$ & & & & 12.6 & 14.7 & 16.9 & 14.02 & 17.9 & 19.9 \\
\hline $\begin{array}{l}\text { Works ewes } \\
\text { carcass(kg) }\end{array}$ & & & & 19.06 & 22.6 & 24.5 & & & \\
\hline $\begin{array}{l}\text { Steer carcass weight } \\
(\mathrm{kg})\end{array}$ & & & & 210 & 275 & 285 & 275 & 272 & 300 \\
\hline Cull cow carcass $(\mathrm{kg})$ & & & & 240 & 250 & 250 & & & \\
\hline Fertiliser $\mathrm{P}(\mathrm{kg} \mathrm{P} / \mathrm{ha} / \mathrm{yr})$ & 17 & 21 & 21 & 17 & 23 & 22 & 19 & 22 & 23 \\
\hline Fertiliser $\mathrm{N}$ (kg N/ha/yr) & None & None & None & None & None & None & None & None & None \\
\hline Male cattle (\%) & 20 & 20 & 20 & 20 & 20 & 20 & 100 & 100 & 100 \\
\hline Finishing stock & No & No & No & No & No & No & Yes & Yes & Yes \\
\hline Slope & Steep hill & Steep hill & Steep hill & Steep hill & Steep hill & Steep hill & Easy hill & Easy hill & Easy hill \\
\hline Fodder crops & None & None & None & None & None & None & None & None & None \\
\hline
\end{tabular}



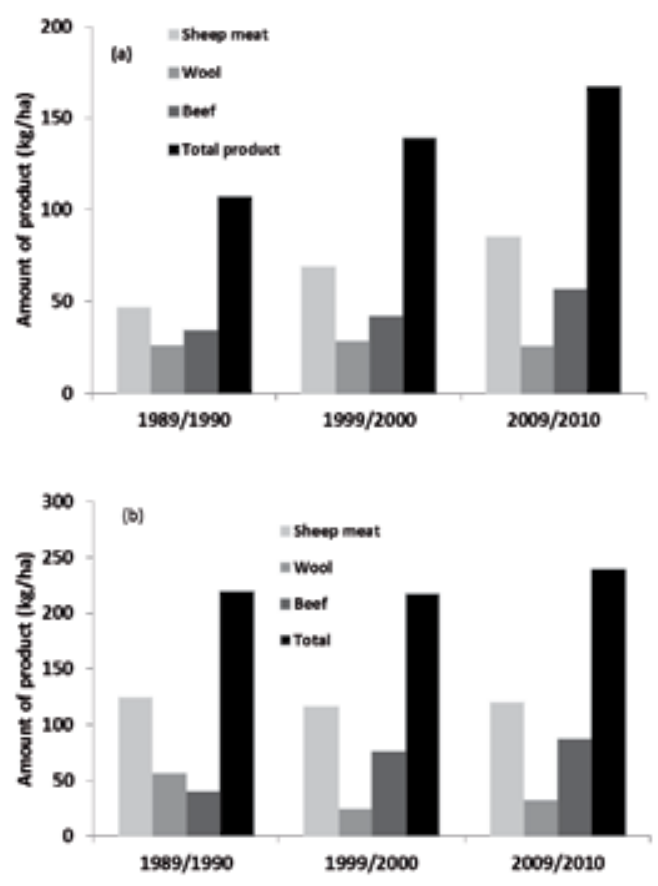

Figure 1. Changes in sheep meat, wool and beef production per hectare from (a) hard hill-Central North Island and (b) easy hill finishing sheep and beef operations since 1989/90

and finished lambs, steers and heifers and cull ewes and cows for both the hard hill country and easy-hill finishing operations are listed in Table 1.

Fibre production per sheep stock unit (su) reported in the MAF Sheep and Beef Farm Monitoring models was multiplied by total sheep stock units and added to sheep and beef meat to calculate meat and fibre production per hectare.

\section{Results and Discussion}

Changes in practices and performance of sheep and beef since $1989 / 90$

There has been little change in the "nominal stocking rates" in the MAF sheep and beef farm monitoring models in the last 20 years (Table 1). For example, the hard hill country stocking rates have shifted from 7.8 to $8.7 \mathrm{su} / \mathrm{ha}$ and the intensive sheep finishing system from 10.3 to $10.6 \mathrm{su} / \mathrm{ha}$ since 1990 . There has also only been "nominal change" in the livestock policy with sheep to cattle ratios showing little change. The shift to hogget mating would be one major change since 1990. Maintenance fertiliser inputs have increased as per hectare production has lifted. It is important to note that the combination of challenging climatic conditions and sub-maintenance fertiliser, as a result of the poor returns in the 3 to 5 years leading up to 2010, probably contribute to an understating of the gains that had been
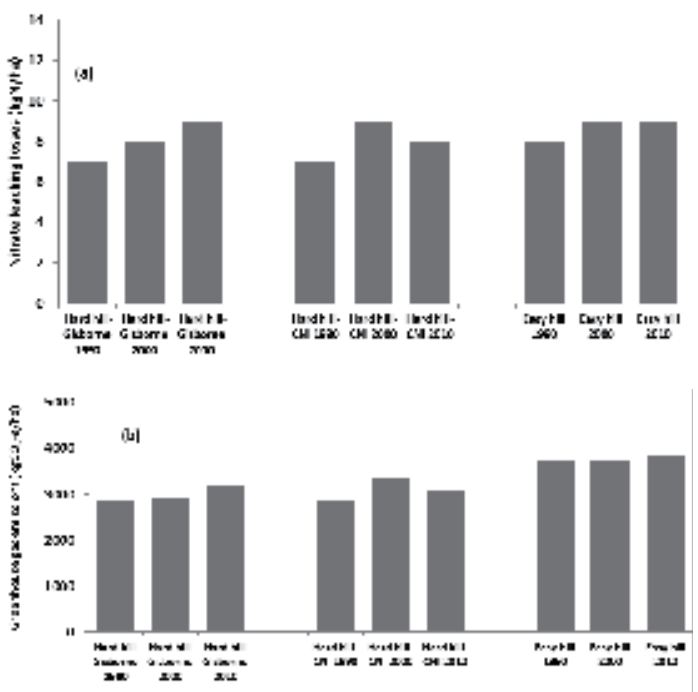

Figure 2. (a) Nitrate leaching losses and (b) greenhouse gas (GHG) emissions from sheep and beef farm systems since 1989/90. The GHG emissions reported here are limited to the methane from animals and nitrous oxide emissions from excreta and applied $\mathrm{N}$ fertiliser. $\mathrm{CNI}=$ Central North Island.

made by the sector since 2000 (Davison 2010).

In sharp contrast to the small changes in livestock numbers, there has been substantial change in livestock performance, with lambing percentages increasing from $75 \%$ to $124 \%$ in the hard hill country-Gisborne sheep and beef farm system and from $93 \%$ to $134 \%$ on the easy hill finishing (Table 1). In addition to the increased ewe fecundity, improvements have also been achieved in lamb growth rates, with slaughter weights of lambs having increased by $37 \%$ from $14.45 \mathrm{~kg}$ to $19.9 \mathrm{~kg}$ over the last 20 years. This has contributed to a lift in sheep meat production in the hard hill country of $72 \%$ since 1989/90 (Fig. 1a). Beef production also increased by more than $50 \%$ over the same period on the hard hill country model farm, while wool production has remained static (Fig. 1a). In the more intensive lowland system, where average MAF Model farm size more than doubled from 173 ha to 368 ha over the 1990-2010 period, there has been little change in eco-efficiency, with amounts of saleable product per ha increasing $<10 \%$ from 219 to $238 \mathrm{~kg} /$ ha over the last 20 years (Fig. $1 b)$.

\section{Changes in nitrate leaching and greenhouse gas emissions}

Nitrate leaching losses calculated using the Overseer nutrient budgeting model for the sheep and beef systems all fell within a narrow range of 7-9 kg N/ha (Fig. 2a). Surprisingly, there was little difference in $\mathrm{N}$ leaching losses between the extensive and more intensive sheep and beef systems. This reflects in part the lower rainfall 
environment of the more intensive operation (Table 1). Despite substantial increases in per hectare production, $\mathrm{N}$ leaching has changed little since 1990 in either the hard hill country or easy hill finishing sheep and beef farm systems. Di \& Cameron (2002) ranked temperate agro-ecosystems based on the potential for causing nitrate leaching in the order: forest $<$ cut grassland $<$ grazed pastures $<$ arable cropping $<$ commercial vegetables. Nitrate leaching losses typically range for forestry from 1 to $5 \mathrm{~kg} \mathrm{~N} / \mathrm{ha} / \mathrm{yr}$, sheep and beef from 6 to $60 \mathrm{~kg} \mathrm{~N} / \mathrm{ha} / \mathrm{yr}$, dairying from 15 to $115 \mathrm{~kg} \mathrm{~N} / \mathrm{ha} /$ $\mathrm{yr}$, arable from 10 to $140 \mathrm{~kg} \mathrm{~N} / \mathrm{ha} / \mathrm{yr}$ and commercial vegetables from 100 to $300 \mathrm{~kg} \mathrm{~N} / \mathrm{ha} / \mathrm{yr}$. The leaching data for the hard hill country and easy hill finishing systems fall at the lower end of the range for sheep and beef systems. In comparison to sheep and beef operations, which are predominantly legume based pasture systems, a dairy farming operation today uses greater amounts of $\mathrm{N}$ fertiliser, brings in supplements, and may graze heifer replacements off the farm for 9 months and winter milking cows off the milking platform for 4 to 6 weeks. All of these serve to increase the amount of $\mathrm{N}$ cycling on the milking platform. This increases the potential for $\mathrm{N}$ leaching losses.

A very similar pattern emerges with GHG emissions as was found with $\mathrm{N}$ leaching, with little change in GHG emissions from the sheep and beef systems over time or across the hard hill country or easy hill finishing farm system (Fig. 2b). The values reported for sheep and beef are in line with other recent published studies (Dynes et al. 2011; Vibart et al. 2011) and less than half those of a dairy system (Beukes et al. 2010).

Understanding how $\mathrm{N}$ leaching losses or GHG emissions change as a consequence of a new technology, a change in a management practices or in response to a market signal is becoming increasingly important as farming within biophysical limits is an emerging property of the future environment the industry will have to operate in. Already there is a N-cap in operation in the Taupo catchment (Environment Waikato 2008) and $\mathrm{N}$ leaching limits in place in priority catchments in the Manawatu-Wanganui Regional (Horizons Regional Council 2012) to reduce the pressure from non-point source contaminants.

\section{Measures of eco-efficiency of sheep and beef}

Meat and fibre production per ha increased (Fig.1a), and the amount of $\mathrm{N}$ leached per $\mathrm{kg}$ animal product and $\mathrm{CO}_{2}$-e per $\mathrm{kg}$ animal product decreased from 1989 to 2000, and again between 2000 and 2010 for the hard hill country-CNI sheep and beef operation (Fig 3a). Total saleable product/ha increased by $47 \%$ (from 107 to $167 \mathrm{~kg} / \mathrm{ha}$ ), nitrate leaching per $\mathrm{kg}$ of saleable product decreased by $21 \%$ (from 0.065 to $0.054 \mathrm{~kg} \mathrm{~N} /$

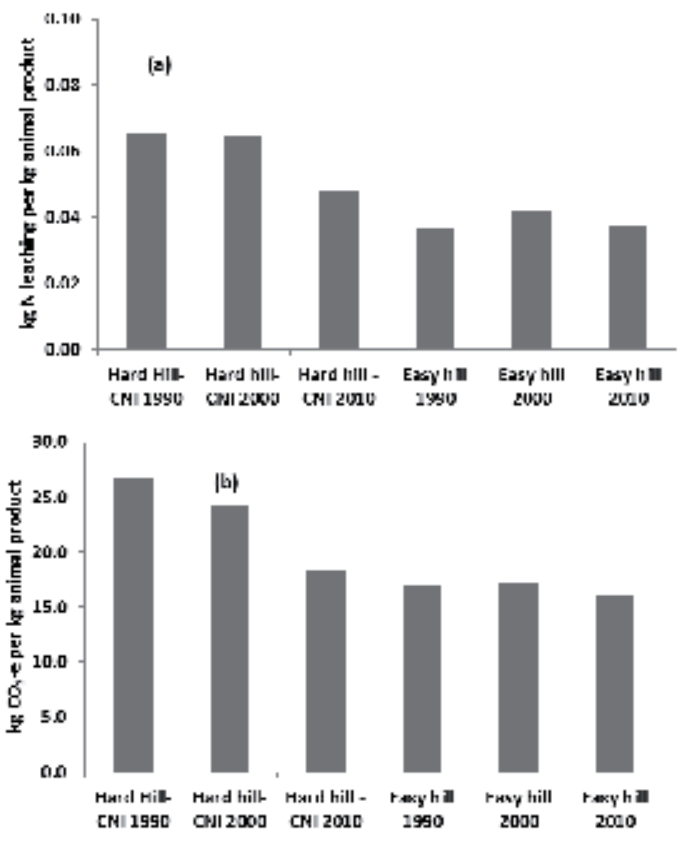

Figure 3: (a) $\mathrm{kg} \mathrm{N}$ leached and (b) $\mathrm{kg} \mathrm{CO}_{2}$-e per $\mathrm{kg}$ animal product (sum of the sheep meat, wool and beef) from sheep and beef farm systems since 1989/90. The greenhouse gas emissions reported here are limited to the methane from animals and nitrous oxide emissions from excreta and any applied $\mathrm{N}$ fertiliser. $\mathrm{CNI}=$ Central North Island.

$\mathrm{kg}$ animal product/ha), and GHG emissions per $\mathrm{kg}$ of saleable product decreased by $40 \%$ (from 27 to $19.2 \mathrm{~kg}$ $\mathrm{CO}_{2}$-e per kg animal product/ha). The GHG emissions per $\mathrm{kg}$ of saleable product values are in line with other recent published studies (Dynes et al. 2011; Vibart et al. 2011). The decrease in the $\mathrm{kg} \mathrm{N}$ leached per $\mathrm{kg}$ of meat and fibre produced reflects two factors. One, more of the feed grown through the spring and summer is eaten by young growing animals that can be turned into saleable product before the autumn and winter months. Second, less liveweight per unit product sold is carried into winter, reducing the number of urine patches and the potential for $\mathrm{N}$ losses by leaching. The reduction in the $\mathrm{kg} \mathrm{CO}_{2}$-e per $\mathrm{kg}$ animal product/ha reflects in part the increased allocation of the total feed grown to saleable product and less to the maintenance of capital livestock.

The eco-efficiency gains obtained in the hard hill country-CNI farm system did not extend to include an overall reduction in $\mathrm{N}$ leaching or GHG emissions per hectare. This is an important point to note if there are limits being set on emissions to water in catchments. In those circumstances the absolute losses per ha are a more meaningful measure of eco-efficiency than the use of a loss per kg product. While there was not an overall reduction in $\mathrm{N}$ leaching or GHG emissions per 
hectare, on the positive side they have changed little since 1990, indicating little change in the environmental footprint by the sector over that period.

In the easy hill finishing system there have been only small changes in the eco-efficiency over the last 20 years (Fig. 3b), but again on the positive side little change in environmental footprint. In comparison to the hard hill country operation, the easy hill finishing system is more eco-efficient with the amount of saleable product per ha higher and the $\mathrm{N}$ leached and GHG emissions per $\mathrm{kg}$ of saleable product lower (Fig. 3). It highlights the fact there is still enormous scope to increase the amount of saleable product on the hard hill country operation through further gains in per head performance. The lambing percentage on the easy hill finishing also has room to move, indicating there are also further gains to be made in the eco-efficiency of this system, as more of the grown pasture feed is directed into young fast growing animals rather than into capital stock. The focus of the sheep industry on reproductive performance and higher growth rates in lambs and cattle provides a natural buffer to the increases in emissions generally associated with intensification of a livestock system.

Understanding how eco-efficiency changes is more than just an academic exercise as we move to an operating environment where land is a finite resource and there are limits on emissions to the environment. The National Policy Statement for Freshwater Management (New Zealand Government 2011) directs Regional Councils to set water quality limits for freshwater objectives, and where these objectives are not met time-bound targets for water quality are to be specified and policy and plans implemented to ensure these are met in the future. Policy development to achieve these requirements will require extending current controls around point source discharges, which represent only a very small percentage of total discharges (Elliott et al. 2005), to diffuse losses from agricultural land (Environment Waikato 2008). This will require the sector to extend objective setting to include an analysis of the impact of the business on the environment.

\section{Conclusions}

For the hard hill country extensive sheep and beef farm operation, the productivity gains made since 1989/90 translate into significant eco-efficiency gains, while for the more intensive sheep and beef operation in the easy hill finishing country the gains have been modest. The two most interesting facts to emerge from the analysis is that there are still major eco-efficiency gains to be made by the sector, with little or no further increase in the sector's environmental foot print. As we move to an operating environment where land is a finite resource and there are limits on emissions to the environment, understanding how eco-efficiency changes is more than just an academic exercise, but will become an increasing important key performance indicator for the sector.

\section{ACKNOWLEDGEMENTS}

The research was funded by the Plant and Food, MSI Core Funded Programme "Sustainable Land Use Initiative."

\section{REFERENCES}

Beef + Lamb New Zealand. 2012. Domestic Trends and Measuring Progress against the Red Meat Sector Strategy. Presentation to Red Meat Sector Conference 16th July 2012. Accessed: September 2012 (http:// www.beeflambnz.com/Documents/Information/ Red\%20meat\%20sector\%20conference.pdf)

Beukes, P.C.; Gregorini, P.; Romera, A.J.; Levy, G.; Waghorn, G.C. 2010. Improving production efficiency as a strategy to mitigate greenhouse gas emissions on pastoral dairy farms in New Zealand. Agriculture, Ecosystems and Environment 136: 358-365.

Davison, R. 2010. Sheep and beef outlook drivers. Beef +Lamb New Zealand Economic Service, Wellington, NZ. Accessed: June 2011. http://www.beeflambnz. com/Documents/Information/Sheep\%20and\%20 beef\%20outlook\%20drivers.pdf

Di, H.J.; Cameron, K.C. 2002. Nitrate leaching in temperate agroecosystems: sources, factors and mitigating strategies. Nutrient Cycling in Agroecosystems 46: 237-256

Dynes, R.A.; Smeaton, D.C.; Rhodes, A.P.; Fraser, T.J.; Brown, M.A 2011. Modelling farm management scenarios that illustrate opportunities farmers have to reduce greenhouse gas emissions while maintaining profitability. Proceedings of the New Zealand Society of Animal Science 71: 149-178.

Elliott, A.H.; Alexander, R.B.; Schwarz, G.E.; Shankar, U.; Sukias, J.P.S.; McBride, G.B. 2005. Estimation of nutrient sources and transport for New Zealand using the hybrid mechanistic-statistical model SPARROW. Journal of Hydrology (NZ) 44:127.

Environment Waikato. 2008. How land use affects Taupo. http://www.ew.govt.nz/Policy-and-plans/ Protecting-Lake-Taupo/\#Heading1 Regional Plan, Variation 5, Environment Waikato, Hamilton, NZ.

Horizons Regional Council. 2012. Environment Court Decisions. Accessed: September 2012. (http://www. horizons.govt.nz/about-us/one-plan/appeals-tothe-proposed-one-plan-as-amended-by-decisionsaugust-2010/environment-court-decisions/)

MAF. 1990. Farm Monitoring Report: A short-term financial and physical forecast reflecting farmer, farm consultant and industry perceptions of farming trends and issues, production and financial figures. Ministry of Agriculture and Forestry. 
MAF. 2000. Sheep and Beef Monitoring Report: A short-term financial and physical forecast reflecting farmer, farm consultant and industry perceptions of farming trends and issues, production and financial figures. Ministry of Agriculture and Forestry. Accessed: September 2012. http://www.mpi.govt. nz/news-resources/publications

MAF. 2010. Farm monitoring Report. A short-term financial and physical forecast reflecting farmer, farm consultant and industry perceptions of farming trends and issues, production and financial figures. Ministry of Agriculture and Forestry. Accessed: September $2012 \mathrm{http}: / /$ www.mpi.govt.nz/news-resources/ publications

New Zealand Government. 2011. National Policy Statement. Freshwater Management 2011. Accessed: 12/5/2011. http://www.mfe.govt.nz/publications/ rma/nps-freshwater-management-2011/docs/npsfreshwater-mgnt-2011.pdf.
Rutledge, D.T.; Price, R.; Ross, C.; Hewitt, A.; Webb, T.; Briggs, C. 2010. Thought for food: impacts of urbanisation trends on soil resource availability in New Zealand. Proceedings of the New Zealand Grassland Association 72: 241-246.

Wheeler, D.M.; Ledgard, S.F.; de Klein, C.A.M. 2008. Using the OVERSEER nutrient model to estimate onfarm greenhouse gas emissions. Australian Journal of Experimental Agriculture 48: 99-103.

Vibart, R.E.; Vogeler, I.; Devantier, B.; Dynes, R.; Rhodes, T.; Allan, W. 2011. Impact of carbon farming on performance, environmental, and profitability aspects of sheep and beef farming systems in Southland. In: Adding to the Knowledge Base for the Nutrient Manager. Eds. Currie, L.D \& Christensen, C.L. http://flrc.massey.ac.nz/publications.html. Occasional Report No. 24. Fertilizer and Lime Research Centre, Massey University, Palmerston North, New Zealand. 13 pp. 